\title{
GAMBARAN TINGKAT KEPUASAN PESERTA BADAN PENYELENGGARA JAMINAN SOSIAL (BPJS) KESEHATAN TENTANG PELAYANAN ADMINISTRASI KEPESERTAAN DI BPJS KESEHATAN KANTOR CABANG UTAMA (KCU) BANDUNG
}

\author{
Mutiafani Hanafi \\ Politeknik Al Islam Bandung \\ Email: muthy71@yahoo.com
}

\begin{abstract}
ABSTRAK
Penelitian ini dilatarbelakangi oleh peningkatan jumlah peserta yang semestinya diikuti oleh peningkatan kualitas jasa yang diberikan oleh pemberi jasa. Banyaknya perusahaan asuransi menuntut para penyedia jasa asuransi untuk selalu meningkatkan kualitas pelayanannya. Permasalahan dalam penelitian ini adalah adanya keluhan peserta terhadap pelayanan administrasi kepesertaan di Badan Penyelenggara Jaminan Sosial (BPJS) Kesehatan Cabang Utama (KCU) Bandung, salah satunya adalah waktu tunggu yang terlalu lama di tempat pengambilan kartu. Metode yang digunakan dalam penelitian ini adalah menggunakan metode deskriptif. Instrumen pengumpulan data menggunakan lembar wawancara dan pengambilan data menggunakan wawancara kepada 30 responden yang datang ke BPJS Kesehatan KCU Bandung. Pengukuran tingkat kepuasan peserta dilakukan dengan membandingkan antara harapan dan kenyataan dengan menggunakan lima dimensi yaitu tangible, reliability, responsiveness, emphaty dan assurance. Berdasarkan hasil penelitian yang dilakukan, tingkat kepuasan peserta BPJS Kesehatan adalah sebagai berikut : dimensi tangible $76,5 \%$ yang berarti bahwa responden merasa puas, dimensi reliability $68 \%$ yang berarti bahwa responden merasa cukup puas, dimensi responsiveness $71 \%$ yang berarti bahwa responden merasa puas, dimensi emphaty $76 \%$ yang menunjukkan bahwa responden merasa puas dan dimensi assurance $69 \%$ yang menunjukkan bahwa responden cukup puas. Secara keseluruhan dimensi tingkat kepuasan peserta mencapai rata-rata $72,1 \%$ yang berada pada tingkat Puas.
\end{abstract}

Kata kunci : dimensi pelayanan jasa, metode deskriptif, tingkat kepuasan

\begin{abstract}
This study is motivated by the improving number of participant and it must be coupled with the increasing quality of service rendered by service providers. Many insurance companies demand the insurance provider to improve the quality of service. The problem in this research is the presence of some complaints from participants of the administrative service in Badan Penyelenggara Jaminan Sosial (BPJS) Kesehatan Kantor Utama (KCU) Bandung, one of the problems is the waiting time is too long in the place of making the cards. The method used in this research is descriptive method. Collection of data use a sheet of an interview, by giving of an interview to the 30 respondent who comes to BPJS. Measuring the level of participant satisfaction by comparing expectation and reality by using five dimensions ; tangible, reliability,
\end{abstract}


responsiveness, empathy and assurance. Based on the result of research conducted, the level of participant satisfaction BPJS are as follows : dimension of tangible 76,5 $\%$, dimension of reliability $68 \%$, dimensions of responsiveness $71 \%$, dimension of empathy $76 \%$ and dimension of assurance $69 \%$, As a whole the dimension of satisfaction level participants attain average 72,1 \% lay on the Satisfied level.

\section{Keywords: dimensions of service quality, descriptive method, level of satisfaction}

\section{PENDAHULUAN}

UUD 1945 pasal $28 \mathrm{H}$ ayat (1) disebutkan bahwa "Setiap orang berhak hidup sejahtera lahir dan batin, bertempat tinggal dan mendapatkan lingkungan hidup yang baik dan sehat serta berhak memperoleh pelayanan kesehatan".

UU no 40 tahun 2004 tentang Sistem Jaminan Sosial Nasional (SJSN), bahwa setiap orang berhak atas jaminan sosial untuk dapat memenuhi kebutuhan hidup yang layak dan meningkatkan martabatnya menuju terwujudnya masyarakat Indonesia yang sejahtera, adil dan makmur.

UU no 24 tahun 2011 tentang Badan Penyelenggara Jaminan Sosial (BPJS), bahwa sistem jaminan sosial nasional merupakan program negara yang bertujuan memberikan kepastian perlindungan dan kesejahteraan sosial bagi seluruh rakyat.

Sistem asuransi kesehatan bertujuan untuk melindungi masyarakat dari kesulitan ekonomi dalam pembiayaan pelayanan kesehatan, serta mendekatkan pelayanan sesuai asas adil dan merata. Pemupukan sumber dana yang didapat dari iuran peserta digunakan sebagai penyelenggaraan pelayanan kesehatan, sehingga pengembangan sarana kesehatan dapat lebih terjamin pada penyelenggaraan kesehatan yang diselenggarakan sesuai dengan prinsip ekonomi.

Pesatnya perkembangan perusahaan asuransi kesehatan baik social maupun komersial menyebabkan kualitas pelayanan menjadi sangat penting. Untuk itu para penyedia jasa harus berusaha untuk meningkatkan kualitas pelayanannya.

BPJS kesehatan merupakan transformasi dari PT Askes Persero. BPJS Kesehatan adalah badan penyelenggara program jaminan kesehatan dari pemerintah yang wajib diikuti oleh seluruh warga negara Indonesia. Untuk itu, dengan luasnya cakupan kepesertaan BPJS Kesehatan mengakibatkan meningkatnya jumlah peserta BPJS Kesehatan pada setiap bulannya. Rata-rata jumlah peserta di Kota Bandung yaitu 817.971 setiap bulannya. Akan tetapi, semakin meningkat jumlah peserta BPJS Kesehatan belum dapat diikuti dengan meningkatnya kualitas pelayanan yang diberikan, hal ini terbukti dengan masih adanya beberapa keluhan yang datang dari peserta, khususnya yang berhubungan dengan pelayanan administrasi kepesertaan di BPJS Kesehatan KCU Bandung. Tujuan Penelitian ini yaitu untuk mengetahui tingkat kepuasan peserta BPJS Kesehatan pada pelayanan administrasi kepesertaan di BPJS Kesehatan KCU Bandung.

\section{METODOLOGI PENELITIAN}

Metode yang digunakan dalam penelitian ini yaitu metode deskriptif, yang berusaha untuk menuturkan pemecahan masalah tentang tingkat kepuasan peserta BPJS Kesehatan pada pelayanan administrasi kepesertaan di BPJS kesehatan KCU Bandung, berdasarkan data-data yang didapatkan di lapangan. 


\section{Teknik Pengumpulan Data}

Teknik pengumpulan data dalam penelitian ini adalah menggunakan :

a. Lembar wawancara

Melakukan wawancara terhadap 30 responden sebagai sampel penelitian. Sampel penelitian meliputi sebagian atau wakil dari seluruh peserta BPJS Kesehatan. Sesuai dengan pendapat Guilford dalam Putri (2013), persyaratan minimal yaitu 30 responden. Penelitian yang diajukan bertujuan untuk menggambarkan tingkat kepuasan responden berdasarkan kualitas jasa yang diberikan dilihat dari 5 dimensi yaitu : tangible, reliability, responsiveness, emphaty dan assurance.

b. Observasi

Dalam penelitian ini penulis secara langsung melakukan observasi kepada peserta BPJS Kesehatan yang melalukan pendaftaran di BPJS Kesehatan KCU Bandung.

c. Studi kepustakaan

Penulis mencari informasi tentang kepuasan pelanggan melalui buku-buku dan media internet untuk mendapatkan bahan materi yang bersangkutan dengan permasalahan yang diteliti oleh penulis.

\section{Teknik Pengolahan Data}

Menjawab rumusan masalah mengenai seberapa jauh tingkat kepuasan peserta BPJS KCU Bandung pada pelayanan adminstrasi kepesertaan yang diberikan, maka digunakan model konseptual mengenai tingkat kepentingan pelanggan.

Dalam hal yang dianggap penting oleh responden terhadap persepsi tentang harapan, digunakan skala likert, yang terdiri dari sangat penting (SP) diberi bobot 5, penting $(\mathrm{P})$ diberi bobot 4, cukup penting (CP) diberi bobot 3, tidak penting (TP) diberi bobot 2, sangat tidak penting (STP) diberi bobot 1 . Sedangkan untuk kinerja yang diberikan atau persepsi responden tentang pengalaman yang dirasakan diberikan penilaian sangat setuju (SS) diberi bobot 5, setuju (S) diberi bobot 4, cukup setuju (CS) diberi bobot 3, tidak setuju (TS) diberi bobot 2, sangat tidak setuju (STS) diberi bobot 1 .

Untuk mengetahui total skor ideal digunakan perhitungan sebagai berikut :

$$
\text { Skor ideal }=\text { skor tertinggi } x \text { jumlah item pertanyaan } x \text { jumlah responden }
$$

Dimensi tangibles, reliability, responsiveness dan assurance menggunakan 4 item pertanyaan, maka skor idealnya adalah sebagai berikut ;
Skor ideal SP dan SS
$=5 \times 4 \times 30=600$
Skor ideal P dan $S$
$=4 \times 4 \times 30=480$
Skor ideal CP dan CS
$=3 \times 4 \times 30=360$
Skor ideal TP dan TS
$=2 \times 4 \times 30=240$
Skor ideal STP dan STS
$=1 \times 4 \times 30=120$

Sedangkan untuk dimensi emphaty menggunakan 3 pernyataan, maka skor idealnya adalah sebagai berikut :

Skor ideal SP dan SS

Skor ideal P dan S

Skor ideal CP dan CS

Skor ideal TP dan TS

Skor ideal STP dan STS

$$
\begin{aligned}
& =5 \times 3 \times 30=450 \\
& =4 \times 3 \times 30=360 \\
& =3 \times 3 \times 30=270 \\
& =2 \times 3 \times 30=180 \\
& =1 \times 3 \times 30=90
\end{aligned}
$$


Menurut Kotler (2000: 134), kriteria untuk menentukan tingkat kepuasan pelanggan atau sering dikenal dengan customer satisfaction index (CSI) yang dicapai adalah sebagai berikut :

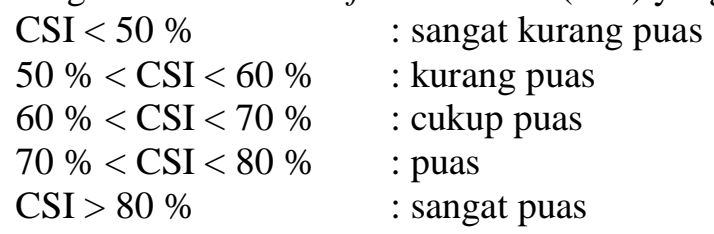

Berdasarkan hasil penilaian kepentingan (harapan) dan kinerja (kenyataan/pengalaman), maka akan dihasilkan suatu perhitungan mengenai kesesuaian antara kepentingan dengan pelaksanaannya di BPJS KCU Bandung. Tingkat kesesuaian adalah hasil perbandingan skor kinerja (kenyataan) dengan skor kepentingan (harapan). Tingkat kesesuaian inilah yang akan menentukan urutan prioritas peningkatan faktor-faktor yang mempengaruhi kepuasan pelanggan.

Penelitian ini adalah menggambarkan tingkat kepuasan peserta antara persepsi harapan dan kinerja (kenyataan). Adapun rumus yang digunakan adalah sebagai berikut :

$$
T K_{i}=\frac{X_{i}}{Y_{i}} \times 100 \%
$$

Keterangan :

$T K_{i}=$ tingkat kesesuaian responden

$X_{i}=$ skor penilaian kinerja (pengalaman) responden

$Y_{i}=$ skor penilaian kepentinan (pengalaman) responden

\section{HASIL DAN PEMBAHASAN}

Dari hasil penelitian, diperoleh beberapa deskripsi yang menyangkut penelitian terhadap responden, yaitu berdasarkan umur, jenis peserta BPJS Kesehatan, pendaftar yang datang, pendidikan terakhir, penilaian responden terhadap tingkat kepentingan (harapan) di BPJS Kesehatan KCU Bandung, penilaian responden terhadap kinerja (pengalaman) di BPJS Kesehatan KCU Bandung, penilaian persepsi responden tentang harapan dan pengalaman yang dirasakan.

Tabel 1.Data Identitas Responden

\begin{tabular}{ccc}
\hline Item & Frekuensi & Presentase (\%) \\
\hline Umur (tahun) & & \\
\hline $17-30$ & 6 & 20 \\
$31-59$ & 21 & 70 \\
$>60$ & 3 & 10 \\
\hline Jenis Peserta & & \\
\hline Pekerja bukan penerima upah & 24 & 80 \\
Askes & 6 & 20 \\
\hline Pendaftar & & \\
Peserta & 19 & 63 \\
Saudara & 6 & 20 \\
Istri & 2 & 7 \\
Lainnya & 3 & 7 \\
\hline SD & & 10 \\
SMP & 2 & 50 \\
SMA & 3 & 33 \\
\hline Perguruan Tinggi & 15 &
\end{tabular}


Sebagian besar usia peserta yang datang ke BPJS Kesehatan KCU Bandung berumur kisaran 31 59 tahun yaitu sebanyak 21 orang atau $70 \%$ dari total keseluruhan responden. Hanya 3 orang atau $10 \%$ responden yang berusia lebih dari 60 tahun. Sebagian besar peserta BPJS Kesehatan yang datang ke kantor BPJS Kesehatan KCU Bandung adalah pekerja bukan penerima upah (PBPU), yaitu berjumlah 24 responden atau $80 \%$ dari jumlah peserta yang berkunjung. Sebagian besar pendaftar BPJS Kesehatan merupakan peserta itu sendiri, dengan jumlah sebanyak $63 \%$ atau 19 orang responden. Peserta yang datang ke kantor BPJS Kesehatan KCU Bandung, sebagian besar adalah lulusan SMA sebanyak 15 orang atau $50 \%$ dari responden

Tabel 2. Penilaian Responden Tentang Tingkat Kepentingan (Harapan) di BPJS Kesehatan KCU Bandung

\begin{tabular}{|c|c|c|c|c|c|c|c|}
\hline \multirow{2}{*}{ No. } & \multirow{2}{*}{ Pernyataan } & \multicolumn{2}{|c|}{ SP } & \multicolumn{2}{|c|}{$\mathbf{P}$} & \multicolumn{2}{|c|}{$\mathbf{C P}$} \\
\hline & & $\mathbf{J}$ & $\%$ & $\mathbf{J}$ & $\%$ & $\mathbf{J}$ & $\%$ \\
\hline \multicolumn{8}{|l|}{ Tangibles } \\
\hline 1 & Kenyamanan dan Kebersihan & 27 & 90 & 3 & 10 & 0 & 0 \\
\hline 2 & Penampilan dan tutur kata yang sopan & 26 & 87 & 3 & 10 & 1 & 3 \\
\hline 3 & Lokasi mudah dijangkau & 28 & 93 & 2 & 7 & 0 & 0 \\
\hline 4 & Fasilitas tempat parkir memadai & 23 & 77 & 6 & 20 & 1 & 3 \\
\hline \multicolumn{8}{|l|}{ Reliability } \\
\hline 5 & $\begin{array}{l}\text { Kemudahan untuk memperoleh buku } \\
\text { petunjuk, brosur / leaflet }\end{array}$ & 25 & 83 & 5 & 17 & 0 & 0 \\
\hline 6 & $\begin{array}{l}\text { Petugas teliti dalam memeriksa persyaratan } \\
\text { pembuatan kartu }\end{array}$ & 28 & 93 & 2 & 7 & 0 & 0 \\
\hline 7 & Kemudahan dalam proses pendaftaran & 28 & 93 & 2 & 7 & 0 & 0 \\
\hline 8 & Sistem nomor antrian berjalan dengan baik & 25 & 83 & 5 & 17 & 0 & 0 \\
\hline \multicolumn{8}{|c|}{ Responsiveness } \\
\hline 9 & $\begin{array}{l}\text { Petugas bersikap cepat tanggap dalam } \\
\text { memberi pelayanan }\end{array}$ & 26 & 87 & 4 & 13 & 0 & 0 \\
\hline 10 & $\begin{array}{l}\text { Petugas bekerja dengan baik dan tidak } \\
\text { membiarkan menunggu terlalu lama }\end{array}$ & 24 & 80 & 6 & 20 & 0 & 0 \\
\hline 11 & $\begin{array}{l}\text { Petugas segera memberi informasi tanpa } \\
\text { harus diminta }\end{array}$ & 28 & 93 & 2 & 7 & 0 & 0 \\
\hline 12 & $\begin{array}{l}\text { Petugas menerima dan menangani keluhan } \\
\text { dengan baik }\end{array}$ & 26 & 87 & 4 & 13 & 0 & 0 \\
\hline \multicolumn{8}{|l|}{ Empathy } \\
\hline 13 & $\begin{array}{l}\text { Petugas sabar, peduli, perhatian menangani } \\
\text { peserta }\end{array}$ & 26 & 87 & 4 & 13 & 0 & 0 \\
\hline 14 & $\begin{array}{l}\text { Komunikasi antara petugas dan peserta } \\
\text { berjalan dengan baik }\end{array}$ & 27 & 90 & 3 & 10 & 0 & 0 \\
\hline 15 & $\begin{array}{l}\text { Petugas ramah dalam melayani peserta dan } \\
\text { menyapa peserta }\end{array}$ & 28 & 93 & 2 & 7 & 0 & 0 \\
\hline \multicolumn{8}{|l|}{ Assurance } \\
\hline 16 & $\begin{array}{l}\text { Petugas selalu ada dan jam buka pelayanan } \\
\text { tepat waktu }\end{array}$ & 26 & 87 & 4 & 13 & 0 & 0 \\
\hline 17 & $\begin{array}{l}\text { Kartu BPJS dapat diperoleh dengan mudah } \\
\text { dan cepat }\end{array}$ & 23 & 77 & 7 & 23 & 0 & 0 \\
\hline 18 & $\begin{array}{l}\text { Petugas bekerja secara professional dan } \\
\text { dapat memuaskan peserta }\end{array}$ & 25 & 83 & 5 & 17 & 0 & 0 \\
\hline 19 & $\begin{array}{l}\text { Petugas bertanggungjawab apabila terjadi } \\
\text { kesalahan }\end{array}$ & 27 & 90 & 3 & 10 & 0 & 0 \\
\hline
\end{tabular}

Keterangan :

$\begin{array}{ll}\mathrm{J} & =\text { jumlah } \\ \mathrm{SP} & =\text { Sangat Penting } \\ \mathrm{P} & =\text { Penting }\end{array}$


$\mathrm{CP} \quad=$ Cukup Penting

Berdasarkan Tabel 2. dapat dijelaskan bahwa : (1) Dimensi Tangible, Pernyataan lokasi BPJS Kesehatan KCU Bandung yang mudah dijangkau, paling banyak dijawab responden "sangat penting" berjumlah 28 orang (93\%) dan paling sedikit menjawab "cukup penting" berjumlah 1 orang (3\%). (2) Dimensi Reliability, Pernyataan petugas teliti dalam memeriksa berkas persyaratan dan pernyataan kemudahan dalam proses pendaftaran, paling banyak dijawab responden "sangat penting" berjumlah 28 orang (93\%) dan paling sedikit menjawab "penting" berjumlah 2 orang (7 $\%)$.

, paling banyak dijawab responden "sangat penting" berjumlah 28 orang (93\%) dan paling sedikit menjawab "penting" berjumlah 2 orang (7\%). (3) Dimensi Responsiveness, Pernyataan petugas segera memberi informasi tanpa harus diminta paling banyak dijawab responden "Sangat penting" berjumlah 28 orang (93\%) dan paling sedikit menjawab "Penting" berjumlah 2 orang (7\%). (4) Dimensi Emphaty, Pernyataan petugas ramah dalam melayani peserta dan menyapa peserta, paling banyak dijawab responden "Sangat penting" berjumlah 28 orang (93\%) dan paling sedikit menjawab "cukup penting" berjumlah 2 orang (7\%). (5) Dimensi Assurance, Pernyataan petugas bertanggung jawab apabila terjadi kesalahan, paling banyak dijawab responden "sangat penting" berjumlah 27 orang $(90 \%)$ dan paling sedikit menjawab "Penting" berjumlah 3 orang $(10 \%)$.

Tabel 3. Penilaian Responden Tentang Kinerja (Pengalaman) yang Dirasakan di BPJS Kesehatan KCU Bandung

\begin{tabular}{|c|c|c|c|c|c|c|c|c|c|c|c|}
\hline \multirow{2}{*}{ No. } & \multirow{2}{*}{ Pernyataan } & \multicolumn{2}{|c|}{ SS } & \multicolumn{2}{|c|}{$\mathbf{S}$} & \multicolumn{2}{|c|}{$\mathbf{C S}$} & \multicolumn{2}{|c|}{ TS } & \multicolumn{2}{|c|}{ STS } \\
\hline & & $\mathbf{J}$ & $\%$ & $\mathbf{J}$ & $\%$ & $\mathbf{J}$ & $\%$ & $\mathbf{J}$ & $\%$ & $\mathbf{J}$ & $\%$ \\
\hline \multicolumn{12}{|c|}{ Tangibles } \\
\hline 1 & Kenyamanan dan Kebersihan & 3 & 10 & 21 & 70 & 4 & 13 & 2 & 7 & 0 & 0 \\
\hline 2 & $\begin{array}{l}\text { Penampilan dan tutur kata yang } \\
\text { sopan }\end{array}$ & 3 & 10 & 22 & 73 & 5 & 17 & 0 & 0 & 0 & 0 \\
\hline 3 & Lokasi mudah dijangkau & 3 & 10 & 21 & 70 & 4 & 13 & 1 & 3 & 1 & 3 \\
\hline 4 & Fasilitas tempat parkir memadai & 1 & 3 & 13 & 43 & 10 & 33 & 6 & 20 & 0 & 0 \\
\hline \multicolumn{12}{|c|}{ Reliability } \\
\hline 5 & $\begin{array}{l}\text { Kemudahan untuk memperoleh } \\
\text { buku petunjuk, brosur / leaflet }\end{array}$ & 0 & 0 & 13 & 43 & 12 & 40 & 5 & 17 & 0 & 0 \\
\hline 6 & $\begin{array}{l}\text { Petugas teliti dalam memeriksa } \\
\text { persyaratan pembuatan kartu }\end{array}$ & 3 & 10 & 17 & 57 & 6 & 20 & 4 & 13 & 0 & 0 \\
\hline 7 & $\begin{array}{l}\text { Kemudahan dalam proses } \\
\text { pendaftaran }\end{array}$ & 0 & 0 & 11 & 37 & 9 & 30 & 10 & 33 & 1 & 3 \\
\hline 8 & $\begin{array}{l}\text { Sistem nomor antrian berjalan } \\
\text { dengan baik }\end{array}$ & 0 & 0 & 16 & 53 & 7 & 23 & 6 & 20 & 1 & 3 \\
\hline \multicolumn{12}{|c|}{ Responsiveness } \\
\hline 9 & $\begin{array}{l}\text { Petugas bersikap cepat tanggap } \\
\text { dalam memberi pelayanan }\end{array}$ & 2 & 7 & 15 & 50 & 9 & 30 & 4 & 14 & 0 & 0 \\
\hline 10 & $\begin{array}{l}\text { Petugas bekerja dengan baik dan } \\
\text { tidak membiarkan menunggu } \\
\text { terlalu lama }\end{array}$ & 2 & 7 & 14 & 47 & 6 & 20 & 8 & 27 & 0 & 0 \\
\hline 11 & $\begin{array}{l}\text { Petugas segera memberi informasi } \\
\text { tanpa harus diminta }\end{array}$ & 1 & 3 & 15 & 50 & 10 & 33 & 4 & 13 & 0 & 0 \\
\hline 12 & $\begin{array}{l}\text { Petugas menerima dan menangani } \\
\text { keluhan dengan baik }\end{array}$ & 0 & & 20 & 67 & 8 & 27 & 2 & 7 & 0 & 0 \\
\hline \multicolumn{12}{|c|}{ Empathy } \\
\hline 13 & $\begin{array}{l}\text { Petugas sabar, peduli, perhatian } \\
\text { menangani peserta }\end{array}$ & 1 & 3 & 21 & 70 & 8 & 27 & 0 & 0 & 0 & 0 \\
\hline 14 & $\begin{array}{l}\text { Komunikasi antara petugas dan } \\
\text { peserta berjalan dengan baik }\end{array}$ & 0 & 0 & 20 & 67 & 9 & 30 & 1 & 3 & 0 & 0 \\
\hline 15 & $\begin{array}{l}\text { Petugas ramah dalam melayani } \\
\text { peserta dan menyapa peserta }\end{array}$ & 1 & 3 & 21 & 70 & 7 & 23 & 1 & 3 & 0 & 0 \\
\hline
\end{tabular}




\begin{tabular}{clllllllllll}
\hline Assurance & 11 & 77 & 11 & 37 & 7 & 23 & 0 & 0 \\
\hline 16 & $\begin{array}{l}\text { Petugas selalu ada dan jam buka } \\
\text { pelayanan tepat waktu }\end{array}$ & 1 & 3 & 11 & & & & & & \\
17 & $\begin{array}{l}\text { Kartu BPJS dapat diperoleh dengan } \\
\text { mudah dan cepat }\end{array}$ & 0 & 0 & 11 & 37 & 10 & 33 & 9 & 30 & 0 & 0 \\
18 & $\begin{array}{l}\text { Petugas bekerja secara professional } \\
\text { dan dapat memuaskan peserta }\end{array}$ & 1 & 3 & 16 & 53 & 11 & 37 & 2 & 7 & 0 & 0 \\
19 & $\begin{array}{l}\text { Petugas bertanggungawab apabila } \\
\text { terjadi kesalahan }\end{array}$ & 7 & 15 & 50 & 11 & 37 & 2 & 7 & 0 & 0 \\
\hline
\end{tabular}

Keterangan :

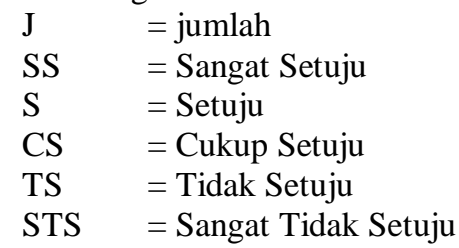

Berdasarkan Tabel 3 dapat dijelaskan bahwa : (1) Dimensi Tangible, Pernyataan penampilan dan tutur kata yang sopan dari petugas, paling banyak dijawab responden "Setuju" berjumlah 22 orang (73\%) dan paling sedikit menjawab "sangat setuju" berjumlah 3 orang (10\%). (2) Dimensi Reliability, Pernyataan petugas teliti dalam memeriksa berkas persyaratan, paling banyak dijawab responden "Setuju" berjumlah 17 orang $(57 \%)$ dan paling sedikit menjawab "sangat setuju" berjumlah 3 orang (10\%). (3) Dimensi Responsiveness, Pernyataan petugas menerima dan menangani keluhan dengan baik, paling banyak dijawab responden "setuju" berjumlah 20 orang (67\%) dan paling sedikit menjawab "Tidak setuju" berjumlah 2 orang (7\%). (4) Dimensi Emphaty, Pernyataan petugas sabar, peduli, perhatian menghadapi peserta, paling banyak dijawab responden "Setuju" berjumlah 21 orang $(70 \%)$ dan paling sedikit menjawab "Sangat setuju" berjumlah 1 orang (3\%). (5) Dimensi Assurance, Pernyataan petugas bekerja secara professional dan dapat memuaskan, paling banyak dijawab responden "Setuju" berjumlah 16 orang (53\%) dan paling sedikit menjawab "Sangat setuju" berjumlah 1 orang (3\%)

Berikut ini merupakan penilaian persepsi responden tentang harapan dan pengalaman yang dirasakan dengan menggunakan perhitungan skala likert, berdasarkan 5 dimensi pelayanan jasa dari hasil wawancara kepada responden.

Tabel 4. Penilaian Persepsi Responden tentang Harapan dan Pengalaman yang dirasakan

\begin{tabular}{|c|c|c|c|c|c|c|c|c|c|c|c|c|}
\hline \multirow{2}{*}{ No. Item } & \multicolumn{5}{|c|}{ Harapan } & \multirow{2}{*}{ Jml } & \multicolumn{5}{|c|}{ Pengalaman } & \multirow{2}{*}{ Jml } \\
\hline & SP & $\mathbf{P}$ & $\mathbf{C P}$ & TP & STP & & SS & $\mathbf{S}$ & CS & TS & STS & \\
\hline \multicolumn{13}{|l|}{ Tangible } \\
\hline 1 & 27 & 3 & 0 & 0 & 0 & 30 & 3 & 21 & 4 & 2 & 0 & 30 \\
\hline 2 & 26 & 3 & 1 & 0 & 0 & 30 & 3 & 22 & 5 & 0 & 0 & 30 \\
\hline 3 & 28 & 2 & 0 & 0 & 0 & 30 & 3 & 21 & 4 & 1 & 1 & 30 \\
\hline 4 & 23 & 6 & 1 & 0 & 0 & 30 & 1 & 13 & 10 & 6 & 0 & 30 \\
\hline Jumlah & 104 & 14 & 2 & 0 & 0 & 120 & 10 & 77 & 23 & 9 & 1 & 120 \\
\hline $\begin{array}{l}\text { Perhitungan Skala } \\
\text { Likert }\end{array}$ & 520 & 56 & 6 & 0 & 0 & 582 & 50 & 308 & 69 & 18 & 1 & 446 \\
\hline \multicolumn{13}{|l|}{ Reliability } \\
\hline 1 & 25 & 5 & 0 & 0 & 0 & 30 & 0 & 13 & 12 & 5 & 0 & 30 \\
\hline 2 & 28 & 2 & 0 & 0 & 0 & 30 & 3 & 17 & 6 & 4 & 0 & 30 \\
\hline 3 & 28 & 2 & 0 & 0 & 0 & 30 & 0 & 11 & 9 & 10 & 0 & 30 \\
\hline 4 & 25 & 5 & 0 & 0 & 0 & 30 & 0 & 16 & 7 & 6 & 1 & 30 \\
\hline Jumlah & 106 & 14 & 0 & 0 & 0 & 120 & 3 & 57 & 34 & 25 & 1 & 120 \\
\hline Perhitungan Skala & 530 & 56 & 0 & 0 & 0 & 586 & 15 & 228 & 102 & 50 & 1 & 396 \\
\hline
\end{tabular}




\begin{tabular}{|c|c|c|c|c|c|c|c|c|c|c|c|c|}
\hline \multicolumn{13}{|l|}{ Likert } \\
\hline \multicolumn{13}{|l|}{ Responsiveness } \\
\hline 1 & 26 & 4 & 0 & 0 & 0 & 30 & 2 & 15 & 9 & 4 & 0 & 30 \\
\hline 2 & 24 & 6 & 0 & 0 & 0 & 30 & 2 & 14 & 6 & 8 & 0 & 30 \\
\hline 3 & 28 & 2 & 0 & 0 & 0 & 30 & 1 & 15 & 10 & 4 & 0 & 30 \\
\hline 4 & 26 & 4 & 0 & 0 & 0 & 30 & 0 & 20 & 8 & 2 & 0 & 30 \\
\hline Jumlah & 104 & 16 & 0 & 0 & 0 & 120 & 5 & 64 & 33 & 18 & 0 & 120 \\
\hline $\begin{array}{l}\text { Perhitungan skala } \\
\text { likert }\end{array}$ & 520 & 64 & 0 & 0 & 0 & 584 & 25 & 256 & 99 & 36 & 0 & 416 \\
\hline \multicolumn{13}{|l|}{ Empathy } \\
\hline 1 & 26 & 4 & 0 & 0 & 0 & 30 & 1 & 21 & 8 & 0 & 0 & 30 \\
\hline 2 & 27 & 3 & 0 & 0 & 0 & 30 & 0 & 20 & 9 & 1 & 0 & 30 \\
\hline 3 & 28 & 2 & 0 & 0 & 0 & 30 & 1 & 21 & 7 & 1 & 0 & 30 \\
\hline Jumlah & 81 & 9 & 0 & 0 & 0 & 90 & 2 & 62 & 24 & 2 & 0 & 90 \\
\hline $\begin{array}{l}\text { Perhitungan skala } \\
\text { likert }\end{array}$ & 405 & 36 & 0 & 0 & 0 & 441 & 10 & 248 & 72 & 4 & 0 & 334 \\
\hline \multicolumn{13}{|l|}{ Assurance } \\
\hline 1 & 26 & 4 & 0 & 0 & 0 & 30 & 1 & 11 & 11 & 7 & 0 & 30 \\
\hline 2 & 23 & 7 & 0 & 0 & 0 & 30 & 0 & 11 & 10 & 9 & 0 & 30 \\
\hline 3 & 25 & 5 & 0 & 0 & 0 & 30 & 1 & 16 & 11 & 2 & 0 & 30 \\
\hline 4 & 27 & 3 & 0 & 0 & 0 & 30 & 3 & 15 & 11 & 2 & 0 & 30 \\
\hline Jumlah & 101 & 19 & 0 & 0 & 0 & 120 & 4 & 53 & 43 & 20 & 0 & 120 \\
\hline $\begin{array}{l}\text { Perhitungan skala } \\
\text { likert }\end{array}$ & 505 & 76 & 0 & 0 & 0 & 581 & 20 & 212 & 129 & 40 & 0 & 401 \\
\hline
\end{tabular}

Keterangan :

$\begin{array}{llll}\text { SP } & =\text { Sangat Penting } & \text { SS } & =\text { Sangat Setuju } \\ \mathrm{P} & =\text { Penting } & \mathrm{S} & =\text { Setuju } \\ \mathrm{CP} & =\text { Cukup Penting } & \text { CS } & =\text { Cukup Setuju } \\ \text { TP } & =\text { Tidak Penting } & \text { TS } & =\text { Tidak Setuju } \\ \text { STP } & =\text { Sangat Tidak Penting } & \text { STS } & =\text { Sangat Tidak Setuju }\end{array}$

Dengan menggunakan perhitungan skala likert, dapat dijelaskan bahwa : (1) Tangible, Skor untuk harapan berada pada angka 582 yang berarti bahwa hasil perhitungan tersebut berada pada posisi mendekati "Sangat penting". Sedangkan skor untuk pengalaman berada pada angka 446, yang berarti bahwa hasil perhitungan tersebut berada pada posisi mendekati "Setuju". (2) Reliability, Skor untuk harapan berada pada angka 582 yang berarti bahwa hasil perhitungan tersebut berada pada posisi mendekati "Sangat penting". Sedangkan skor untuk pengalaman berada pada angka 396, yang berarti bahwa hasil perhitungan tersebut berada pada posisi mendekati "Cukup Setuju". (3) Responsiveness, Skor untuk harapan berada pada angka 584 yang berarti bahwa hasil perhitungan tersebut berada pada posisi mendekati "Sangat penting". Sedangkan skor untuk pengalaman berada pada angka 416, yang berarti bahwa hasil perhitungan tersebut berada pada posisi mendekati "Cukup Setuju”. (4) Emphaty, Skor untuk harapan berada pada angka 441 yang berarti bahwa hasil perhitungan tersebut berada pada posisi mendekati "Sangat penting". Sedangkan skor untuk pengalaman berada pada angka 334, yang berarti bahwa hasil perhitungan tersebut berada pada posisi mendekati "Setuju". (5) Assurance, Skor untuk harapan berada pada angka 581 yang berarti bahwa hasil perhitungan tersebut berada pada posisi mendekati "Sangat penting”. Sedangkan skor untuk pengalaman berada pada angka 401, yang berarti bahwa hasil perhitungan tersebut berada pada posisi mendekati "Cukup Setuju”.

Berdasarkan hasil penilaian kepentingan (harapan) dan kinerja (Pengalaman), maka akan dihasilkan suatu perhitungan mengenai tingkat kesesuaian (tingkat kepuasan) yang merupakan perbandingan/perhitungan antara harapan yang diinginkan dan pengalaman yang telah dirasakan. Tingkat kesesuaian adalah hasil perbandingan skor kinerja (pengalaman) dengan skor kepentingan 
(harapan). Tingkat kesesuaian inilah yang akan menentukan urutan prioritas peningkatan faktorfaktor yang mempengaruhi kepuasan pelanggan.

Tabel 5. Tingkat Kepuasan Responden

\begin{tabular}{|c|c|c|c|c|}
\hline No. & Pernyataan & $\begin{array}{l}\text { Pengalaman } \\
\qquad(\mathbf{X i})\end{array}$ & $\begin{array}{l}\text { Harapan } \\
\quad(\mathbf{Y} \mathbf{i})\end{array}$ & $\begin{array}{c}\text { Tingkat } \\
\text { Kepuasan } \\
\text { (TKi) }\end{array}$ \\
\hline \multicolumn{5}{|c|}{ Tangibles } \\
\hline 1 & Kenyamanan dan kebersihan & 115 & 147 & $78 \%$ \\
\hline 2 & Penampilan dan tutur kata yang sopan & 118 & 145 & $81 \%$ \\
\hline 3 & Lokasi mudah dijangkau & 114 & 148 & $77 \%$ \\
\hline 4 & Fasilitas tempat parkir memadai & 100 & 142 & $70 \%$ \\
\hline \multicolumn{5}{|c|}{ Reliability } \\
\hline 5 & $\begin{array}{l}\text { Kemudahan untuk memperoleh buku } \\
\text { petunjuk, brosur / leaflet }\end{array}$ & 99 & 145 & $68 \%$ \\
\hline 6 & $\begin{array}{l}\text { Petugas teliti dalam memeriksa persyaratan } \\
\text { pembuatan kartu }\end{array}$ & 109 & 148 & $74 \%$ \\
\hline 7 & Kemudahan dalam proses pendaftaran & 92 & 148 & $62 \%$ \\
\hline 8 & System nomor antrian berjalan dengan baik & 98 & 143 & $68 \%$ \\
\hline \multicolumn{5}{|c|}{ Responsiveness } \\
\hline 9 & $\begin{array}{l}\text { Petugas bersikap cepat tanggap dalam } \\
\text { memberi pelayanan }\end{array}$ & 105 & 146 & $72 \%$ \\
\hline 10 & $\begin{array}{l}\text { Petugas bekerja dengan baik dan tidak } \\
\text { membiarkan menunggu terlalu lama }\end{array}$ & 99 & 144 & $69 \%$ \\
\hline 11 & $\begin{array}{l}\text { Petugas segera memberi informasi tanpa harus } \\
\text { diminta }\end{array}$ & 103 & 148 & $69 \%$ \\
\hline 12 & $\begin{array}{l}\text { Petugas menerima dan menangani keluhan } \\
\text { dengan baik }\end{array}$ & 108 & 146 & $74 \%$ \\
\hline \multicolumn{5}{|c|}{ Empathy } \\
\hline 13 & $\begin{array}{l}\text { Petugas sabar, peduli, perhatian menangani } \\
\text { peserta }\end{array}$ & 113 & 146 & $77 \%$ \\
\hline 14 & $\begin{array}{l}\text { Komunikasi antara petugas dan peserta } \\
\text { berjalan dengan baik }\end{array}$ & 110 & 147 & $75 \%$ \\
\hline 15 & $\begin{array}{l}\text { Petugas ramah dalam melayani peserta dan } \\
\text { menyapa peserta }\end{array}$ & 112 & 148 & $76 \%$ \\
\hline \multicolumn{5}{|c|}{ Assurance } \\
\hline 16 & $\begin{array}{l}\text { Petugas selalu ada dan jam buka pelayanan } \\
\text { tepat waktu }\end{array}$ & 96 & 146 & $66 \%$ \\
\hline 17 & $\begin{array}{l}\text { Kartu BPJS dapat diperoleh dengan mudah } \\
\text { dan cepat }\end{array}$ & 92 & 143 & $64 \%$ \\
\hline 18 & $\begin{array}{l}\text { Petugas bekerja secara professional dan dapat } \\
\text { memuaskan peserta }\end{array}$ & 105 & 145 & $72 \%$ \\
\hline 19 & $\begin{array}{l}\text { Petugas bertanggungjawab apabila terjadi } \\
\text { kesalahan }\end{array}$ & 107 & 147 & $73 \%$ \\
\hline
\end{tabular}

a. Tangibles (Bukti Langsung)

Pada dimensi ini penyataan penampilan dan tutur kata yang sopan memiliki presentase kepuasan paling tinggi yaitu $81 \%$. Hal ini terbukti dengan penampilan petugas BPJS Kesehatan yang terlihat rapi dan tutur kata para petugas yang sopan. Sedangkan pernyataan fasilitas tempat parkir memadai memiliki presentase paling rendah yaitu $70 \%$. Pada dasarnya lahan parkir BPJS Kesehatan KCU Bandung memang kurang memadai sehingga pengunjung terkadang bingung untuk menyimpan kendaraannya. 
b. Reliability (Keandalan)

Pada dimensi ini, pernyataan petugas teliti dalam memeriksa berkas persyaratan memiliki presentase kepuasan paling tinggi yaitu $74 \%$. Hal ini terbukti pada saat proses pendaftaran, petugas secara teliti memeriksa kelengkapan persyaratan dan pada saat mengentry data peserta, petugas tidak seenaknya mengisi data peserta sendiri, tapi petugas secara langsung menanyakan kepada peserta agar tidak terjadi kesalahan. Sedangkan pernyataan kemudahan dalam proses pendaftaran memiliki presentase paling rendah yaitu $62 \%$. Ada beberapa keluhan yang datang dari peserta diantaranya mengenai sistem nomor antrian yang belum rapi, sehingga peserta harus mengantri lama hanya untuk mengambil nomor antrian, karena di BPJS Kesehatan KCU Bandung menggunakan 2 kali nomor antrian. Kemudian alur proses pendaftaran peserta yang procedural sehingga peserta mau tidak mau harus mengikuti prosedur yang ada walaupun alur proses pendaftaran tersebut membutuhkan waktu yang lama. Proses pendaftaran per orangan dari pertama antri sampai mendapatkan kartu membutuhan waktu yang lama, yaitu hampir setengah hari waktu buka kantor.

c. Responsiveness (ketanggapan)

Pada dimensi ini, pernyataan petugas menerima dan menangani keluhan dengan baik, memiliki presentase tingkat kepuasan paling tinggi yaitu $74 \%$. Hal ini terbukti dengan adanya usaha petugas untuk selalu menyelesaikan permasalahan dan membuat peserta nyaman atas pelayanan yang diberikan. Sedangkan pernyataan petugas bekerja dengan baik dan tidak membiarkan peserta menunggu terlalu lama memiliki presentase paling rendah yaitu $69 \%$. Pada dasarnya pelayanan administrasi kepesertaan sudah berjalan dengan baik, hanya saja pada saat pengambilan kartu peserta harus menunggu lama, dikarenakan para petugas sudah mempunyai tugas masing-masing dan tidak adanya petugas khusus untuk mencetak kartu peserta, sehingga harus menunggu salah satu petugas menyelesaikan atau menyisakan waktu luang untuk mencetak kartu. Selain itu peserta merasa tidak puas karena kurangnya informasi yang meluas dari pihak BPJS, sehingga masih banyak masyarakat yang tidak tahu bagaimana cara mendaftar BPJS meskipun BPJS Kesehatan telah melakukan sosialisasi melalui iklan, tapi ternyata masih saja tidak mengerti cara mendaftar dan tidak mengetahui manfaatnya.

d. Empathy (Empati)

Pada dimensi ini, pernyataan petugas sabar, peduli, perhatian dalam menghadapi peserta memiliki persentase kepuasan paling tinggi yaitu $77 \%$. Hal ini terbukti dengan persepsi baik dari responden tentang petugas yang memperhatikan pelanggan.

e. Assurance (Jaminan)

Pada dimensi ini, pernyataan petugas bertanggung jawab apabila terjadi kesalahan memiliki persentase kepuasan paling tinggi yaitu $73 \%$. Hal ini dibuktikan dengan kesiapan petugas menjelaskan dan menangani masalah apabila terjadi suatu kesalahan. Sedangkan pernyataan kartu BPJS dapat diperoleh dengan mudah dan cepat, memiliki persentase paling rendah yaitu $64 \%$. Ini terlihat bahwa peserta harus menunggu dalam waktu yang lama untuk mendapatkan kartu BPJS Kesehatan. Selain itu, faktor yang mempengaruhi ketidakpuasan peserta yaitu kuota yang diberikan oleh BPJS terlalu sedikit, sedangkan peserta yang mendaftar sangat banyak sehingga terkadang ada peserta yang harus bolak-balik ke BPJS karena tidak mendapat nomor antrian. 
Tabel 6. Rata-Rata Tingkat Kepuasan berdasarkan Dimensi Pelayanan Jasa

\begin{tabular}{cc}
\hline Dimensi & Rata-rata Kepuasan $(\%)$ \\
\hline Tangibles & 76,5 \\
Reliability & 68,0 \\
Responsiveness & 71,0 \\
Emphaty & 76,0 \\
Assurance & 69,0 \\
\hline Jumlah & 360,5 \\
\hline Rata-rata & 72,1 \\
\hline
\end{tabular}

Tingkat kepuasan responden paling tinggi dengan presentase $76,5 \%$ yang berarti responden merasa puas, terletak pada dimensi tangibles (bukti langsung). Hal ini terbukti tidak adanya keluhan, responden merasa nyaman atas penampilan dan tutur kata petugas. Sedangkan tingkat kepuasan responden paling rendah dengan presentase $68,0 \%$ yang berarti responden merasa cukup puas, terletak pada dimensi reliability (Kehandalan). Hal ini sesuai dengan adanya keluhan dari responden mengenai proses pendaftaran yang terlalu lama, khususnya dalam pembuatan kartu.

Rata-rata tingkat kepuasan dari seluruh dimensi ini adalah $72,1 \%$ yang menunjukkan bahwa responden merasa puas dengan seluruh pelayanan administrasi yang diberikan oleh BPJS Kesehatan KCU Bandung.

\section{SIMPULAN}

Dari 5 dimensi pengukuran kualitas jasa, untuk dimensi tangibles (bukti langsung) responden menyatakan puas dengan presentase rata-rata adalah 76,5\%, dimensi reliability (kehandalan) responden menyatakan cukup puas dengan presentase rata-rata adalah $68 \%$, dimensi responsiveness (ketanggapan) responden menyatakan puas dengan presentase rata-rata adalah $71 \%$ dan dimensi emphaty responden menyatakan puas dengan presentase rata-rata adalah $76 \%$, serta dimensi assurance (jaminan) responden menyatakan cukup puas dengan presentase rata-rata adalah $69 \%$

Rata-rata tingkat kepuasan secara keseluruhan adalah 72,1\% yang menunjukkan bahwa responden merasa puas dengan seluruh pelayanan administrasi yang diberikan oleh BPJS Kesehatan KCU Bandung. 


\section{DAFTAR PUSTAKA}

Ali, Faried. [2013]. Teori dan Konsep Administrasi. (Cet.3). Jakarta : Rajagrafindo Persada.

Badan Penyelenggara Jaminan Sosial Kesehatan. Buku Pedoman Pelayanan Administrasi Kepesertaan.

Company Profile BPJS Kesehatan. dipetik Mei 2014, 30 dari : http://wwww.bpjs-kesehatan.go.id

Ferdianto, Aang. UUD 1945 Pasal $28 \mathrm{H}$. [online]. Tersedia: http://grabaggrubug.blogspot.com/2010/03/uud-1945-pasal-28-h.html [04 Februari 2014].

Kotler, Philip. 2000. Manajemen Pemasaran Analisis Perencanaan Implementasi dan Pengendalian. Jakarta: Erlangga.

Lupioadi, Rambat. 2013. Manajemen Pemasaran. [Edisi 3]. Jakarta : Salemba Empat.

Nasution. 2004. Manajemen Jasa Terpadu. Jakarta : Ghalia Indonesia

Putri, Erna Agustina. 2013. Tingkat Kepuasan Pasien Umum Rawat Jalan di Rumah Sakit Mata Cicendo. Tugas akhir yang tidak dipublikasikan. Bandung: Politeknik Al Islam Bandung. Rangkuti, Freddy. 2006. Measuring Costumer Satisfaction. Jakarta : Gramedia Pustaka Utama. Tjiptono, Fandy. 2006. Pemasaran Jasa. Malang : Bayumedia . 